\title{
The Concept of Ministry in the Arabic Political Tradition Its origin, development, and linguistic reflection
}

\author{
IVAN V. SIVKOV
}

\begin{abstract}
The paper presents the results of an analysis of the term "ministry" (wizāra) as one of the pivotal concepts in the Arabic/Islamic political tradition. The ministry as key political/administrative institution in the Arabic/Islamic traditional state machinery is researched from a historical/institutional perspective. The concept of ministry is treated from the point of its origin and historical development, as well as its changeable role and meaning in the variable Arabic political system. The paper is primarily dedicated to the investigation of the realization of the concept of ministry and its different types and branches in the Arabic language through the etymological and semantic examination of the terms used to denote this institution during the long period of administrative development of the Arabic world from its establishment as such and during the inception of the 'Abbāsid caliphate to its usage in administrative apparatus of modern Arab states. The paper is based on Arabic narrative sources such as historical chronicles, collections of the official documents of modern Arabic states, and the lists of its chief magistrates (with special reference to government composition and structure).
\end{abstract}

Keywords: term, terminology, concept, semantic, etymology, value, derivation

\section{Introduction}

The term wazì is traditionally used to denote the position of vizier who was the state secretary, the aide, helper and councilor of the caliph/sultan of the highest rank in the administrative apparatus of 'Abbāsid Caliphate and its successor states (e.g., Būyids, Fātimids, Ayyūbids and Salğūqs). In the modern administrative interpretation this term signifies the minister in all Arab and some Muslim states. The notion of minister/ministry passed through different stages of its lexical and institutional development from Umayyad scribe (secretary, kätib) to modern wazìr. The present paper is the investigation of the etymology of the term wazir and political formation of the institution of vizierate up to the establishment of 'Abbāsid caliphate in $750 \mathrm{CE}$.

\section{The term wazìr and its etymology}

The lexeme wazìr occurs in the Qur'ān where Aaron (Hārūn) is twice called "the helper" (wazīr) of Moses $(M \bar{u} s \bar{a})$ : 
wa-ğal lī wazīr ${ }^{a n}$ min ahlī (XX: 29) "And appoint for me a helper from my family"; 1

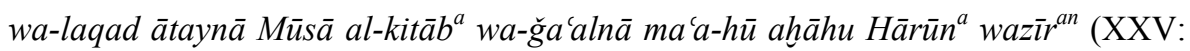
35) "And indeed We gave Mûsâ (Moses) the Scripture [the Taurât (Torah)], and placed his brother Hârûn (Aaron) with him as a helper", ${ }^{2}$ where, according to classical commentators, it means "helper"; "supporter" ('awn; mu'ìn; zahīr; mu'äzir

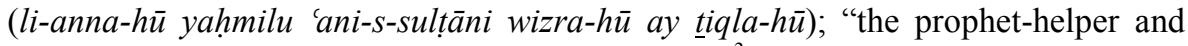
supporter" (nabiyy muwāzir wa-mu'ayyid wa-nāșir). ${ }^{3}$

The question of the etymology of the term vizier (wazīr) is thoroughly treated in the works of Sh.D. Goitein and D. Sourdel. They examine views of Classical Arabic and Western scholars on the problem of etymology of the term wazir and come to the conclusion that both term and institution of vizierate (wizāra $)^{4}$ have an Arabic origin.

The views of the majority of scholars of vizierate are divided regarding the question of the origin of the title vizier (wazir). Some early Western scholars suppose that this term has Persian origin. F. Babinger states that the word wazìr and the idea of vizierate (wizāra) comes from Iran (in the Avesta vicira means "decider", "judge", in Pehlevi v(i)čir "judge", "decision"). He claims that the Arabs undoubtedly took over the term in the Sassanid period and it was only in later times that modern Persian took back wazir from the Arabic as if it were originally Arabic. ${ }^{5}$

Th. Nöldeke holds the term wazìr likely to be of Pehlevi origin, but he states that the Pehlevi term wačîr has only an abstract meaning. He advances the theory that the term wezìrpat (= gezîrpat, pat "ruler", "monarch", "potentate") probably meant "subaltern minister" and was borrowed into the Arabic language with the omission of pat. ${ }^{6}$

J. Darmesteter supports the idea put forward by Th. Nöldekeand argues that the term vicir (<vi-cira "decider") was borrowed by the Arabs and became Vizîr. ${ }^{7}$ It appeared in the

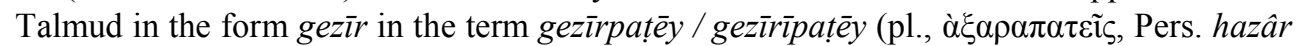
paiti $<*$ vicirô-pati ${ }^{8}$ ) "name of a class of oppressive Persian officers (chiliarchi)": Ta ănith, 20a; Sanhedrin, 98a; Sabbath, 139a). ${ }^{9}$

Sh. D. Goitein and D. Sourdel refer to M. Sprengling, who in his article "From Persian to Arabic" tries to find the Persian etymon of the term wazir. He affirms that the Pehlevi term vicir meaning "a legal document" or "decision" is not used alone to designate an office, rank, or any functionary great or small within the Sassanian Empire. This etymon is

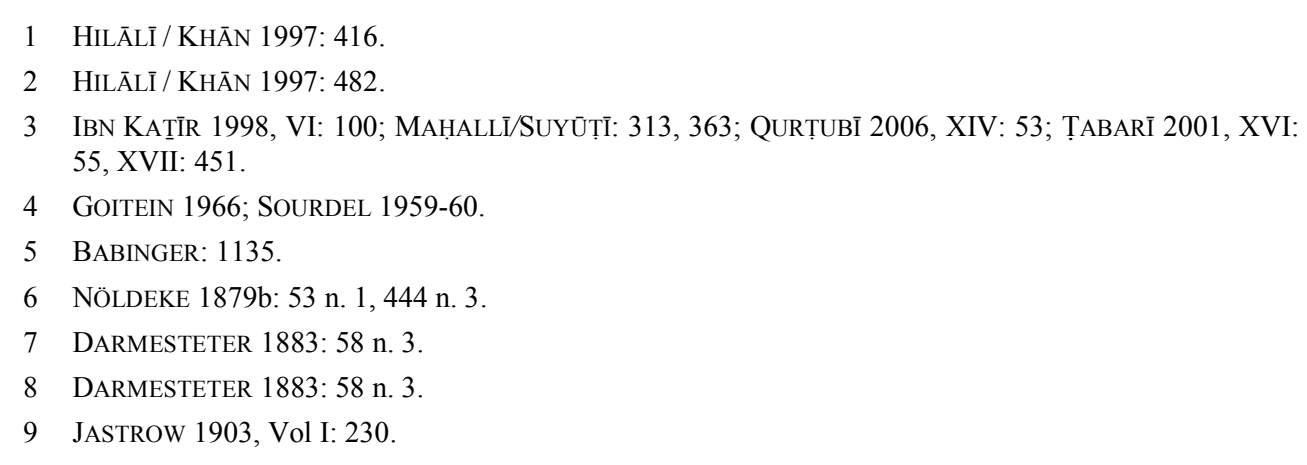


also found in the Persian loan-word gezirpat that was initially noticed by Th. Nöldeke (see above). It was used in the Babylonian Talmud in the mid-fifth century as title of a village official of low rank, who supervised arable lands and irrigation and who was compared by G. Hoffman with the Syriac term reš geziraye that was used in "Actes syriaques des martyrs" (fifth century) to denote the chief of police. ${ }^{10} \mathrm{M}$. Sprengling states that the term gezirpat was no more than the chief of village or the commissar of police; thus he couldn't have even a remote connection with the vizier who was minister of state, often Prime minister in Muslim states and empires. ${ }^{11}$

P. Horn proposes a Persian etymology for the term wazīr (gezīr, gizīr, < Avestan vīcira "decider", Pehlevi v(i)čīr "decision", "decider", “judge"). ${ }^{12} \mathrm{H}$. Masse states, referring to A. Meillet, that this term is of Persian origin and ultimately comes from Avestan vičira (vičira) "decider", in Pehlevi wčyr. ${ }^{13}$

E. G. Browne suggests that the term wazir is derived from Arabic wizr "a burden" because the vizier bears the burden of administration but, referring to J. Darmesteter (see above), and that this term was identical with Pahlavi vi-chir (<vi-chirá "to decide", gazir in the Talmud). ${ }^{14}$

Traditional Arabic historiographers and political thinkers insist on the exclusively Arabic provenance of the term wazìr. For example, al-Māwardī, Badr ad-Dīn ibn Ğamā'a and Halīl aẓ-Zāhirī suggest an exclusively Arabic derivation of this term:

1. wizr (pl. awzār) "a heavy load or burden (tiql)", because he takes up the heavy burdens of the king;

2. wazar "a place of refuge (malğa)", because the king takes refuge in his judgement and his aid;

3. azr "back (zahr)", because the king gains strength in his minister just as the body is strengthened by the back. ${ }^{15}$

'Abd al-Malik at-Ta'âlibī proposes combined Arabo-Persian source of the derivation of the term wazìr:

1. wizr "a heavy load or burden (tiql)", because he takes up the heavy burdens of the king;

2. i'äna "aid", "help", "assistance", because the minister assists the king with taking up heavy burdens.

3. Arabicized (mu'arrab) Persian zūr, zor "strength", "power", "force". 16

Hilāl aṣ-Șābī presents a purely Arabic derivation of this term:

10 GOITEIN 1966: 170; SOURDEL, I: 45-6.

11 SOURDEL, I: 45-6.

12 HORN 1893: 242-3 n. 1084.

13 IBN EL-ÇAÏRAFĪ 1914: 80 n. 2.

14 BROWNE 1908: 255-6.

15 IBN ĞAMĀ'Ā 1985: 75; MĀWARDī 1976: 64-5; MĀWARDī 1979: 137-8; MĀWARDī 1989: 33; ẒĀHIRĪ 1894: 93.

16 T̃A ĀLIBĪ 1993: 21-2. 
1. wazar "a place of refuge (malğa)", because the king takes refuge in his judgement and his aid;

2. awzār (singular wizr) "clothing (amtica)", because he is in charge of the wardrobes and clothing of the king;

3. wizr "a heavy load or burden (tiql)", because he takes up the heavy burdens of the king;

4. azr "back (zahr)", because the king gains strength in his minister just as the body is strengthened by the back. ${ }^{17}$

Traditional Arabic lexicographers ${ }^{18}$ present the detailed network of derivatives of the root $w-z-r$ with the following values:

1. "a heavy burden"; "a $\sin$ (sense development "burden of soul" > "sin" by metaphorical extension)":

wizr "a heavy load or burden (tiql, al-himl at-taqīl)"; "a bundle that is carried on the back"; "a weight"; "(pl. awzār) a weapon (silāh)"; "an instrument of war (ālātu-hā

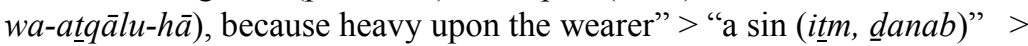

- vb. I wazara (vn. wazr, wizr) "he bore, or carried a heavy load, or burden (hamala-hī)";

- vb. I wazira (vn. wizr, wazr, zira, or wizra) "he sinned (atima), or he bore a burden of sin" >

○ act.part. I wāzir, pass.part. I mawzūr "bearing, or carrying a heavy load or burden" > "sinning or bearing a burden of sin";

- vb. VIII ittazara "he committed a wizr (itm), i.e. a sin";

- vb. I wazara (vn. wazr) "he overwhelmed him". ${ }^{19}$

2. "refuge" >

- wazar "a mountain: a mountain difficult of access or strong, or a mountain to which someone betakes himself for refuge" > "a place of refuge (malğa', ma'qil, mu'tașam, semantic shift by metaphoric extension" >

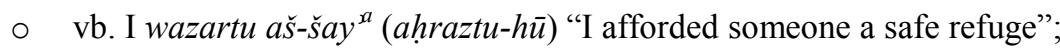

○ vb. IV awzara-hū (vn. $\bar{z} z \bar{a} r$ ) "he appointed someone a wazar i.e. a place of

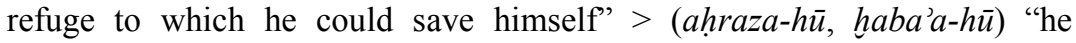
afforded a safe refuge to someone" > (semantic shift) "he concealed

\section{7 ȘĀBĪ, n. h.}

18 AZHARī 1964-1967, XIII: 246-7; FĪRŪZĀBĀDĪ 2005: 492; IBN MANZŪ̄R 1981, VI: 4823-4; IBN SīDAH

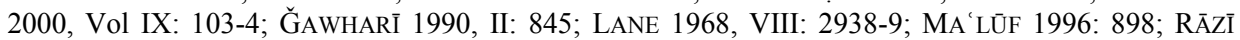
1986: 299; ZABĪDĪ 1965, XIV: 358-362; ZAMAHֵŠARİ 1996: 482.

19 DE BIBERSTEIN KAZIMIRSKI 1860, II: 1527. 
someone"; "he carried something off", "he took something away"; "he abducted, stole something"; "he destroyed/annihilated something/someone".

Verbs I-IV have denominative character. They established common value "to use someone as place of refuge" from "place of refuge" by semantic extension "a thing" > "to use this thing".

As was stated above, the term wazìr is thought by Classical Arabic lexicographers to be the derivate of:

1. wizr: (i.e. muwāzir < wāzara (see below), pl. wuzarāa', awzār) "someone who bears a burden or burdens (yahmil wizr $^{a n}$, i.e. tiql) with another, or someone who aids, assists or helps and strengthens another (mu'äwin)" > "the person who bears with the king the burdens of the of the royal office and aids him with his counsel (haba'

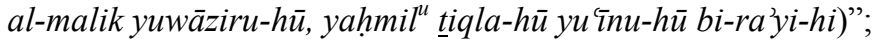

2. wazar: "someone upon whose counsel the caliph relies in his affairs, and to whom he saves himself for refuge or safety (wazīr al-halīfa al-lād̂̀ ya'tamidu 'alā ra'yi-hi fi-umūri-hi wa-yaltaği'u ilay-hi)".

- In the Classical Arabic lexicographic and historiographic sources a whole number of the denominative verbal derivatives of the term wazis with the general value "to be/became a vizier/to be appointed a vizier" acquired by the semantic shift "the name of a institution" > "to be appointed as head of this institution", are attested:

- vb. I wazara (li-, vn. wazāra); vb. V tawazzara (li-) "he was, or became vizier (wazīr) to someone":

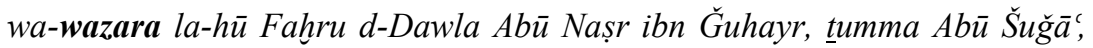
țumma 'Amīdu d-Dawla Abū Manșūr ibn Ğuhayr "Faḩr ad-Dawla Abū Nașr ibn Ğuhayr was his vizier and after him-Abū Šuğăe' and after him-'Amīd ad-Dawla Abū Manșūr ibn Ğuhayr", ${ }^{20}$

wa-kāna qad tawazzara li-'Aḍdi d-Dawla "He was the vizier of 'Aḍud adDawla"; ${ }^{21}$

- wizāra/wazāra (vn. of vb. I wazara, wazāra is the variant (lugia) of wizāra, which is more approved $(a l \bar{a}))$ "the condition or office of a wazìr":

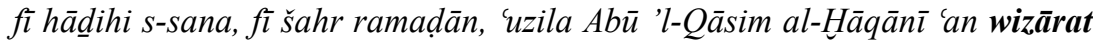
al-halīfa "In this year, in the month of Ramaḍān, Abū 'l-Qāsim al-Ȟāqānī was dismissed from the vizierate of the caliph", ${ }^{22}$

- vb. X istawzara-hū "he took someone, or chose someone as a wazīr": ustūzira fulān un "someone was taken, or chosen as a wazìr":

20 IBN AL-AṬīR 1987-2003, VIII: 487.

21 IBN TAǴRĪBIRDĪ 1992, IV: 133.

22 IBN AL-AT̄īr 1987-2003, VII: 24. 
wa-fi-hā istawzara s-Sultạn Tugiril-bik wazīra-hū Abā l-Qāsim 'Alī ibn

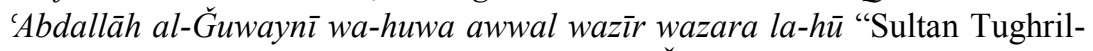
bik took Abū 'l-Qāsim 'Alī ibn 'Abdallāh al-Ğuwaynī as his_vizier (wazìr) and he was the first who was his vizier". 23

The root $w-z-r$ is firmly established in the Arabic root corpus. Its reflections are attested in several Semitic languages where the root is regarded to be secondary, shared by the lexemes proposed to be related to Arabic or simply Arabic loanwords.

- The Old Hebrew hapax legomenon wāzār is attested in the Bible (occurring Proverbs 21:8) in the word combination $\imath_{\bar{s}}$ wāzār "crooked, guilty" (probably related to Arabic wazara "he bore a burden" or to wazira "was guilty"), ${ }^{24}$

- Gə`əz wazara "to plaster, overlay (with wood), decorate a wall" (probably from Arabic wazara "fill up a fissure" (see below)), ${ }^{25}$

- Amharic wäzzärä "to decorate, adorn" (probably derived from wäyzäro (1));

- Amharic täwäzzärä "to be decorated, adorned"; "to sit idly, to be idle, unoccupied"; 27

- Gə`əz wezaro "lady”28 (from Amharic wizäro (wezäro, wäyzäro "madame, lady,

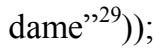

- Amharic wäyzäro (1) "vizier, chief of the palace, highborn (all those who are descended from the royal family)"; ${ }^{30}$

- Amharic wäyzär "noble who has received office and awards, handsome person of royal descent". ${ }^{31}$

The root ' $z-r$ with the common meaning "strength"; "assistance" is perceived in traditional Arabic lexicography ${ }^{32}$ as a variant of the root $w-z-r$ (see above). The latter root is seen as being derived from ' $-z-r$ by the omission of hamza (tahfif al-hamza). The ' $-z-r$ - derivatives are represented with the following values:

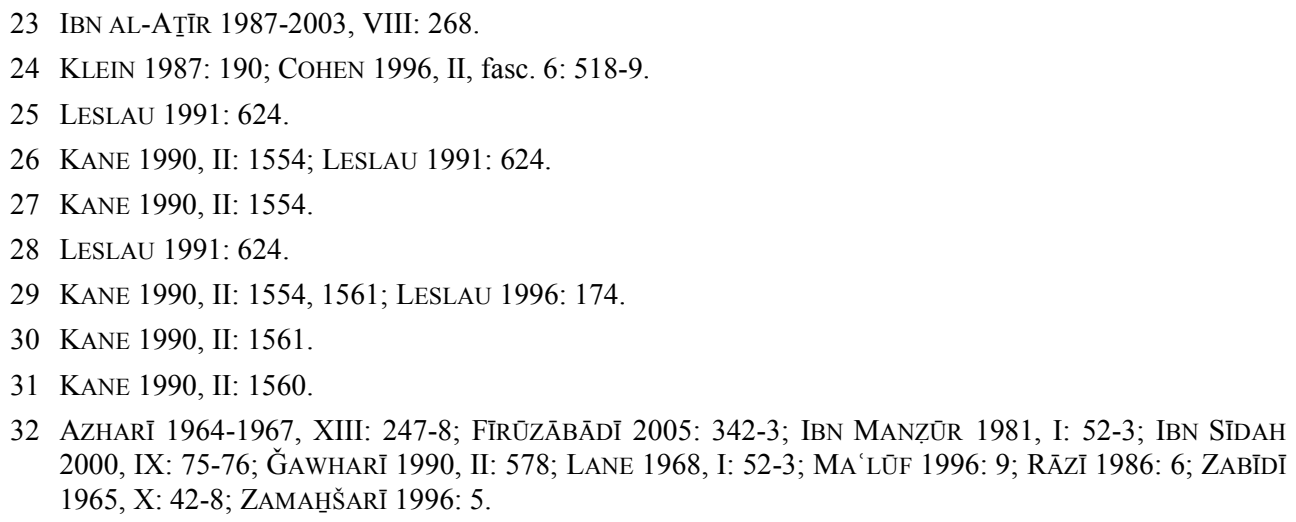


1. "surrounding", "covering" >

- $i z \bar{a} r^{33}$ "long wrapper for cowering the lower part of the body from the waist downwards, loincloth" > e.g., "any structural device which goes all round a room" (e.g., skirting-board, decorative groove between wall surface and ceiling surface, < "loincloth", metaphorical extension on the common meaning "support") ${ }^{34}>$

○ vb. I azara (vn. azr) "to surround something"; "35 "he put on him, or clad him with an izār";

- vb. II azzara "he put on him, or clad him with an izāa"; "to clothe someone with an izār"; "it covered it"; "to cover, wrap up something/someone"; "36 "he cased the lower part of a wall and thus strengthened it";

○ vb. V ta'azzara; vb. VIII i'tazara/îtazara "to put on an $i z \bar{a} r$, wrap oneself in an $i z \bar{a} r{ }^{\prime \prime}{ }^{37}$

Verbs I-VIII are evidently of the denominative type. They developed a general value "to surround", "to cover" from "loincloth" by semantic extension "a thing" $>$ "to perform the action by this thing";

2. "strength"> "help", "assistance" >

- $a z r$ : "strength (quwwa)", "weakness $\left(\right.$ da $\left.f^{38}\right)$; "the back (zahr)" >

○ vb. I azara-hū (vn. azr);

○ vb. II $a z z a r a-h \bar{u}$ (vn. $\left.t a^{\prime} z \bar{\imath} r\right)$;

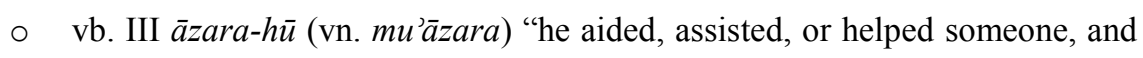

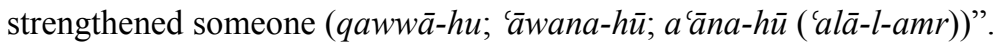

Verbs I-III can clearly be classified as denominative with a semantic shift "strength" > "to give the strength" > "to help, aid, assist".

Some ' $-z-r$ - and $w-z-r$ - derivatives are lexical duplicates:

- izār, izr $\leftrightarrow w_{i z r a}{ }^{39} /$ wazra $^{40}$ "loincloth" that is suggested to be the derivate of the root ${ }^{3}-z-r^{41}>$

\footnotetext{
33 In all Classical Arabic lexicographical sourced referred to in the present paper the terms izr, izāra, mi'zar, mi'zara are given as synonymous to $i z \bar{a} r$ (e.g., LANE 1968, I: 52-3).

34 BADAWI / HINDS 1986: 16.

35 WEHR / COWAN 1980: 1064.

36 WEHR / COWAN 1980: 1064.

37 WEHR / COWAN 1980: 1064.

38 In this case azr can be considered an auto-antonymous (enantiosemantic) lexeme.

39 WEHR / COWAN 1980: 1064.

40 De BiBerstein KAZIMIRSKi 1860, II: 1528; DOZY 1881, Vol, II: 799; WAHRMUND 1887, II: 1180.

41 COHEN 1996, II, fasc. 6: 518-9.
} 
○ vb. III $\bar{a} z a r a-h \bar{u} \leftrightarrow w \bar{a} z a r a-h \bar{u}$ "he bore a burden with someone": yuwāzir ${ }^{u} l$ wazir" l-malik $a b \bar{a}^{a}$ l-mulk "he bore with the king the burden of the royal

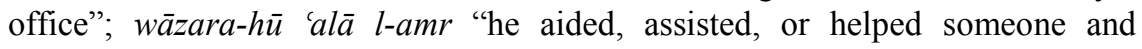

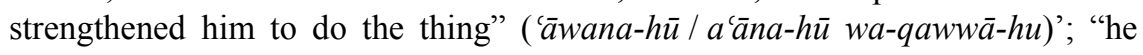
was, or became wazīr to someone";

○ vb. VIII i’tazara/ītazara ↔ ittazara "to wear a loincloth"; "to put on (a garment)". ${ }^{42}$ Its value "wear a loincloth" emerged as a result of semantic extension "a thing" > "to perform the action by this thing";

○ wazara "skirt, skirting (arch.)",43 (< "loincloth", metaphorical extension of the common meaning "surrounding"; "covering"; "putting on");

- Egyptian wazara "any structural device, such as a baseboard, which goes around a room"; "lintel"44 (< "loincloth", metaphorical extension of the common meaning "support");

○ vb. I wazara (vn. wazr) "fill up a fissure" (< "loincloth", metaphorical extension of the common meaning "covering"). ${ }^{45}$

Sh. D. Goitein states that the term wazir is often found in poetry, both contemporaneous with Muhammad and in the Umayyad period. ${ }^{46}$ In poetical and historiographical sources it is used in the general meaning "helper", "assistant", "aide", "advisor". For example, it was conveyed by the Arabic historiographic tradition that the first caliph Abū Bakr responded to the Anșār who claimed the emirate: "min-nā-l-umarā" wa-min-kum al-wuzarā"; "Nahnu-l-umarā' wa-antum al-wuzarā" (We are the amīrs (umarā') and you are the wazìrs $(w u z a r \bar{a})) .{ }^{47}$ Abū Bakr complained about being called amīr. Instead of being addressed as $a m \bar{\imath} r$ he preferred to be simply wazīr. ${ }^{48}$ Ziyād ibn Abīhi, Abū 'l-Mugīira (622 or 623/4673 ), the secretary (kātib) of the governors of al-Kūfa, Bașra, and once more al-Kūfa, Abū Mūsā ibn Qays al-Ašcarī is called wazīr. ${ }^{49}$ 'Abdallāh ibn Ġāfil ibn Habīb ibn Hudayl ibn Mas'ūd (died 652/3), who was appointed as the assistant to the Governor of al-Küfa, 'Ammār ibn Yāsir ibn 'Āmir ibn Mālik Abū 'l-Yaqzān (died 657), is called by aṭ-Ṭabarī "councilor" and "assistant" (mu'allim and wazīr). ${ }^{50}$ The governor of al-Kūfa, Abū Muhammad al-Hağğāğ ibn Yūsuf ibn al-Hakam ibn 'Aqīl at-Taqafī (born about 661 — died 714) named 'Āmir ibn Abī Mūsā Abū Burda al-Aš́arī (died in 721/722 or 722/723) qā d̄ (judge) of al-Kūfa and also appointed $\mathrm{Sa}^{\mathrm{i}} \overline{\mathrm{i}} \mathrm{d}$ ibn Ğubayr (665-714) his assistant, who is

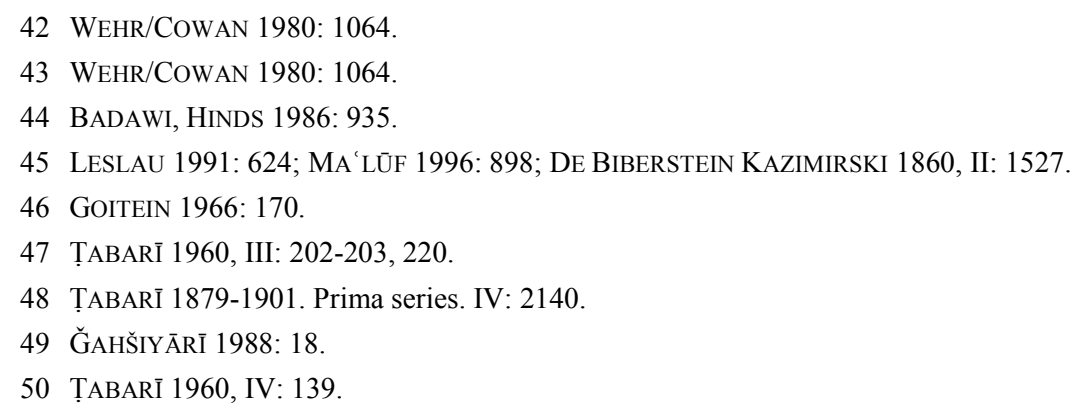


called kātib (secretary) and wazīr. ${ }^{51} Q \bar{a} d \bar{l}$ (judge) of Bașra, Abū Wātila Iyās ibn Mu'āwiya ibn Qurra al-Muzan̄̄ (died 739 or 740) appointed Hāalid al-Had̄āà his councilor and assistant (șāra wazīr ${ }^{a n}$ wa mušīr $\left.{ }^{a n}\right) .{ }^{52}$ 'Abd al-Hamīd ibn Yahyā ibn Sacd (died 750), the chief secretary of Umayyad caliph Marwān ibn Muhammad (died in 750, ruled 744-750) occupied the vizierate (taqallada 'Abd al-Hamīd wizärat Marwān). ${ }^{53}$

The leader of the early $\breve{S}_{1}$ 'i (pro-'Alīd) revolt in al-Kūfa, al-Muhtār ibn Abī 'Ubayd atTaqafĩ (622 - 687) styled himself "the helper of the family of Muhammad (wazīr $\overline{A l}$ Muhammad)". ${ }^{54}$ Abū Salama Hafṣ ibn Sulaymān al-Hallāl, the leader of the Šīi i movement in al-Kūfa (killed in 750), was named "the helper of the family of Muhammad (wazīr $\overline{A l}$ Muhammad)" and later was appointed vizier (wazīr) by the first 'Abbāsid caliph Abū 'l'Abbās as-Saffāh (died 754, ruled 750-754) in 749. ${ }^{55}$

From its original general meaning of "helper", the term wazìr gradually acquired the sense of "representative (or deputy)", and, under the 'Abbāsids, designated the highestranking civil functionary of the state next to the caliph.

The semantic development of Arabic wazìr can be correlated with the semantic shift in English minister (Old French menistre "servant", "valet", "member of a household staff", "administrator" < Latin minister "inferior", "servant", "priest's assistant" (in Medieval Latin, "priest") < minus, minor "less" > "subordinate" + comparative suffix *-teros, formed on model of magister) from "one who acts upon the authority of another" to "high officer of the state" (in political sence, from notion of "service to the crown"). ${ }^{56}$

One can see that the denominative verbs wazara, tawazzara and istawzara, derived from the term wazir , acquired their semantics on the basis of the meaning shift "the name of position" > "to hold this position" / "to appoint someone to this position".

\section{The origin and establishment of the institution of vizierate}

The majority of scholars investigating the institution of the vizierate (wizāra) is divided concerning the question of its origin. Most early Western scholars suppose that this institution has Persian origin. F. Babinger suggests that the idea of vizierate (wizāra) originates in Iran. ${ }^{57}$

A. Christensen believes that the position of vizierate (wizāra) as it became to be known in Caliphate times and later was conserved in all Muslim states, was directly borrowed from the Sassanid Empire and suggests that the prototype of vizier (wazìr) was the

\footnotetext{
51 IBN QUTAYBA, I: 62.

52 WAKI'‘, I: 317.

53 ĞAHŠIYĀRİ 1988: 55.

54 ZAMAN 2002: 185 (with reference to Goitein S.D. The origin of the vizierate and its true character. Studies in Islamic History and Institutions. Leiden: E.J. Brill, 1966. Appendix on the origin of the term vizier: 194-6).

55 ĞAHŠIYĀRİ 1988: 56-7; ZAMAN 2002: 185.

56 Online Etymology Dictionary; available online at $<$ http://etymonline.com $>$.

57 BABINGER: 1135.
} 
Sassanid wuzurg framadār/framādhār/framātā $r^{58}$ ("the grand vizier", in Arabic sourcesbuzurğframad $\bar{a} r^{59}$ ) - the highest ranking official of the Sasanian state, the head of the central administration. ${ }^{60}$ In Old Persian, the substantive framātar (composed of the prefix fra- "before", "forth" + root $m \bar{a}+$ agent suffix -tar) is translated as "master", "lord (giver of judicial decisions)" ${ }^{61}$ The Achaemenids used this term in their royal titles. The term was passed into Parthian in the form of prmtr in order to designate an office, probably that of the director of public supplies (e.g., wine, barley, etc.). ${ }^{62}$ A. Christensen states that in the beginning the title of the head of the central administration was hazārbadh. Already in the

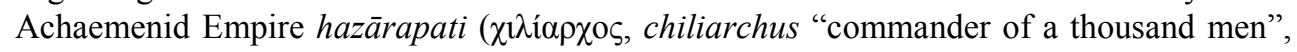
in Armenian sources - hazarapet) was the chief officer of the Empire. This title continued to be used in Parthian times till the Sassanian period. ${ }^{63}$

Sh.D. Goitein supposes that A. Christensen used the description of the vizierate by alMāwardī, Muslim lawyer and political theoretician of XI century, due to the considerable lack of material. ${ }^{64}$

The classical Arabic lexicographers tell us that the Lahmid kings of al-Hīra appointed their assistants and helpers, which were called ridf (ridf al-malik). The term ridf (pl. 'ardāf) is attested in the classical Arabic dictionaries with its original values "one who rides behind another on the back of the same beast"; "a sequent of a thing, whatever that thing be"; "the consequence of an event or affair"; "aids, assistants or auxiliaries (as being man's follower) because when any one of them is fatigued, another take his place"; "the hinder part of anything"; "the posteriors or buttocks (or peculiarly, according to some, of a woman)". ${ }^{65}$ Thus, it is evident that the word ridf obtained its terminological meaning "the aide, assistant and co-ruler of the king" from the value "one who rides behind another on the back of the same beast" by metaphorical extension.

In the pre-Islamic times (al-Ğăhiliyya, the "Time of Ignorance") ridfs supplied the place of the king (malik) in the management of the affairs of the realm, like the wazir or the șăhib aš-šurta in the time of Islam. They sat on the right hand of the king and, when the king drank, drank after him, before others, and, when the king went to war, sat in his place, and were his vice-regents (halīfa) over the people until he returned, and, on the return of

58 CHRISTENSEN 1907: 19, 30, 32-4, 56, 80; CHRISTENSEN 1944: 99, 114, 130, 136, 265, 271, 352, 411-2, 519.

59 JA'QUBI 1883, Vol I: 202; MASÛDî 1894: 103; MAS'ŪDĪ 1938: 91 (explained in Arabic as wazīr, akbar ma'mûr); YA 'QŪBī 2010, I: 222 (interpreted in Arabic as wazīr, mutaqallid al-umūrr).

60 CHAUMONT 2001: 125-6; CHRISTENSEN 1907: 33; CHRISTENSEN 1944: 113-6.

61 KeNT 1950: 197-8.

62 CHAUMONT 2001: 125-6.

63 CHRISTENSEN 1944: 113-4.

64 Christensen 1907: 33-4; Christensen 1944: 115-6; GoITEIN 1966: 168.

65 AZHARĪ 1964-1967, XIV: 96-7; FĪrŪZĀBĀDĪ 2005: 812; IBN MANẒ̛̂R 1981: III: 1625-6; IBN SīDAH 2000, IX: 302-4; ĞAWHARĪ 1990, IV: 1363-4; LANE 1968, III: 1068; MA'LūF 1996: 256; RĀZī 1986: 101; ZABĪDĪ 1965, XXIII: 328, 335. 
the king's army, took the fourth of the spoil (mirbāa). He also rode behind the king upon his horse. $^{66}$

The term ridâfa (vn. with general value "the name of office from ridf") denotes the function of the ridf of a king (ridf al-malik) in the pre-Islamic (al-Ğăhiliyya) times. It was similar to hilāfa and wizāra in the Islamic period. The position of ridāfa pertained to Banū Yarbū', because there were not among the Arabs any who waged war more than they did against the kings of al-Hiira, who therefore made peace with them on the condition that the ridâfa should be assigned to them and that they should abstain from waging war against the people of al-'Irāq. ${ }^{67}$

The term ridf motivated the derivation of the value "to act as a ridf or as ardāf to the kings" in vb. III rādafa (vn. murādafa: murādafat al-mulūk "the acting as a ridf or as ardāf to the kings") and vb. IV ardafa (vn. irdāf) on the basis of semantic shift: "the name of a position" > "to hold a position".

This term has cognates in the Semitic languages (Hebrew rā $\underline{d} a p^{-" t o}$ pursue, chase"; "to persecute"; Jewish Palestinian Aramaic-Syriac $r^{e} \underline{d} a p^{-~ " h e ~ p u r s u e d, ~ c h a s e d, ~ p e r s e c u t e d " ; ~}$ Mandaic $r d p$ "to pursue, chase, persecute"). ${ }^{68}$

M. Enger mentions the "Acta S. Arethae" (also called "Martyrium sancti Arethae" or

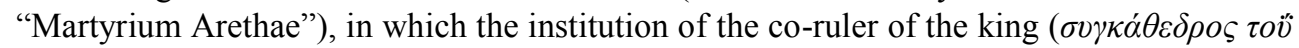
$\beta \alpha \sigma l \lambda \dot{\varepsilon} \omega \varsigma)$ of Nağrān and the narrative of Classical Arabic lexicographers about the existence of the institution of ridāfa in al-Hīra (see above) are attested, and states that the institution of vizier in the form known in Islamic times was passed to the kingdom of alHīra as vassal state of Sassanid Empire from Iran because it was the part of Persian political system and was transmitted to the 'Abbāsid caliphate. He says that with the advent of Islam this institution changed its name from ridf to wazìr. ${ }^{69}$ But, as D. Sourdel notes, M. Enger doesn't take into consideration the interruption of the period of Umayyad caliphate. ${ }^{70}$

W. Barthold criticizes the views of A. Christensen about the direct borrowing of the position of vizierate from the Sassanid Empire with its prototype in vuzurg framādhār. He affirms that the term wazìr is definitely of Arabic origin and rules out its development from Sassanid buzurg-framāâa $r$ because this institution was maintained until the sixth century and disappeared in the late Sassanid period. He underlines the idea that the buzurgframā $\underline{d} \bar{a} r$ was the omnipotent Chief Minister and military commander of the Sassanid Empire whose institution looked more like the Frankish majordomus then the 'Abbāsid vizier. ${ }^{71}$ In one of the oldest Middle Persian (Pahlavi) texts of ancient Iranian epic poetry "Yātkār-i Zarīrān" (Memorial of Zarēr) the title of Chief Minister written in Aramaic in the

66 AZHARĪ 1964-1967, XIV: 97-8; De SACY 1822: 278-9; IBN MANZŪR 1981, III: 1626; IBN SīDAH 2000, IX: 303; ĞAWHARĪ 1990, IV: 1363-4; LANE 1968, III: 1068; MA LūF 1996: 256; FīrŪZĀBĀDī 2005: 812; ZABĪDĪ, XXIII: 328-9, 331.

67 AZHARĨ 1964-1967, XIV: 97-8; De SACY 1822: 278-9; FīrŪZĀbĀDī 2005: 812; IBN MANZ̄ūr 1981, III: 1626; ĞAWHARĪ 1990, IV: 1363-4; LANE 1968, III: 1068; MA'LŪF 1996: 256; ZABĪDĪ 1965, XXIII: 331.

68 KLEIN 1987: 608.

69 ENGER 1859: 240-1.

70 SOURDEL 1959-60, I: 42.

71 BARTHOLD 1912: 257-60. 
form of byt $\bar{t} h$ was compared by the translator of the text with the New Persian hanneg $\bar{\imath}$ (domesticus). ${ }^{72}$

R. A. Nicholson believes that the office of vizier is probably of Persian origin but he refers to M. J. de Goeje's opinion that the term wazìr itself is Arabic. ${ }^{73}$

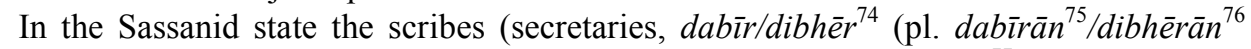
"bureaucracy" < Mid. Pers. dibir < Achaemenid Elamite tup-pi-ra, ${ }^{77}$ in the Persian translation of "the Letter of Tansar" - kotta $b^{78}$ ) constituted one of the four classes in Sassanian society. Secretaries were commissioned to handle the royal correspondence and record the orders of the king and his high officials. They were also charged with recording everyday events and chronicles, and some of them served in various state offices (dīvāns) or were engaged in writing, compiling, and copying books. ${ }^{79}$

The chief secretary of Sassanid Iran had the title dibirbed (attested in the Parthian documents from Nisa as dpyrpty) ${ }^{80}$ In the Arabic and Persian sources this title was given as dabìrbad $\underline{d}^{81} /$ dabîrbedh ${ }^{82} /$ dibhêrbadh, ${ }^{83}$ or dabirfad ${ }^{84} /$ dabirfad..$^{85}$ Another title for the chief secretary was Pahlavi dabīrān/dapīrān/dibhērān mahišt (more officially Ërāndabìrbad/dapirrbad/dabîrbedh/dibhērbadh), ${ }^{86}$ which was translated in the Persian sources as mehtar-e dabīran, ${ }^{87}$ mehtar dabīr ${ }^{88}$ or bozorg dabīr. ${ }^{89}$

The institution of $k \bar{a} t i b$ (secretary) apparently corresponded with the Sassanid dabirpat. ${ }^{90}$ Morphologically, the lexeme kātib is an act.part. from vb. I kataba "to write"

72 GEIGER 1891: 53.

73 NiCHOLSON 1907: 256.

74 CHRISTENSEN 1944: 57, 132.

75 Christensen 1907: 19, 38.

76 CHRISTENSEN 1944: 98.

77 RAJABZADEH / TAFAŻŻOLĪ 1993: 534-9.

78 DARMESTETER 1894: 214.

79 RAJABZADEH / TAFAŻŻOLĪ 1993: 534-9.

80 RAJABZADEH / TAFAŻŻOLĪ 1993: 534-9.

81 ĞĀHIZ 1914: 77, 160, 173 (explained by Arabic hăfiz al-kitāb (with reference to al-Mas'ūdī), in the opinion of editor al-Kitāb means the Sacred Book of Zoroastrians (al-Kitāb al-Muqaddas inda-lMağuss)); JA'QUBI 1883, vol. I: 202 (compared with Arabic al-kātib); MAS'ŪDĪ 1938: 91 (correlated with Arabic hậfiz al-kitäb); YA'QŪBĪ 2010, I: 222.

82 CHRISTENSEN 1907: 19, 30, 40.

83 CHRISTENSEN 1944: 99, 265, 519.

84 EBN AL-BALH̄ī 1385 SH: 49.

85 MiSKAWAYH 2003, I: 78 (interpreted in Arabic as al-mutaqallid li-dīwān ar-rasā̄il)

86 BoyCe 1968: 41, 61; BROWNe 1900: 231 (dabir-badh); CHRISTENSEN 1907: 20, 32, 40, 55, 81, 94; CHRISTENSEN 1944: 99, 134-6, 302, 395, 412; DARMESTETER 1894: 544; GEIGER 1891: 48; NÖLDEKE 1878: 62.

87 DARMESTETER 1894: 240, 544.

88 Šăh-nāme 1960-71, VII: 127 v. 271.

89 ȚABARİ/BEL'AMI 1867-1874, II: 260, 267-8, 278, 301.

90 BARTHOLD 1912: 260.

$J A I S$ • 15 (2015): 227-244 
with the basic grammatical value "someone who writes" that was nominalized and extended to "writer". Then it underwent the semantic shift "writer" > "a scribe"; "a secretary" during its being transformed to term.

The institution of kattib already existed in Arabia at the time of Prophet Muhammad. ${ }^{91}$ Al-Ğahšiyārī begins his list of secretaries $(k u t t a \bar{b})$ and wazīrs with the secretaries of the Prophet Muhammad and says that he had different kinds of sectetaries $(k u t t \bar{a} b)$, among them those who wrote down Qur'ān verses (kuttāb al-wahy) —'Alī ibn Abī Ṭālib (killed in 661, caliph 656--661), 'Uțmān ibn 'Affān (killed in 656, caliph 644-656) and in the case of their absence-Ubayy ibn Ka'b al-Anșārī al-Madan̄̄ (died between 640 and 656) and Zayd ibn Tābit (died between 662/3 and 675/6; later was one of the secretaries of caliphs Abū Bakr and 'Umar ibn al-Hattāa (killed in 644, caliph 634-644)). ${ }^{92}$

The late Sassanids had no wazurg-framadār (chief minister) and the Umayyads had no wazìr. ${ }^{93}$ "Righteous" caliphs (al-ȟlafä' ar-rāšidūn) and their Umayyad successors regularly appointed the secretaries $(k u t t \bar{a} b)$ for themselves. 'Abbāsid caliphs gave the name wazìr as title to the minister who was formerly called kātib (secretary) and it would seem that the Arabic wazir (literally "burden-bearer"), who was at first merely a "helper", afterwards became the representative and successor of the dapir (official scribe or secretary) or the Sasanian kings. ${ }^{94}$

W. Barthold supposes that the 'Abbāsids' elevation of the kātib to the wazīr was an innovation called by the development of the cultural life that might be only artificially connected with the Sassanid institutions. ${ }^{95}$

Several denominative verbal derivatives of the term kātib are attested in Classical Arabic lexicographical and historiographic sources: ${ }^{96}$

- kataba (li-) "he was/became a kātib (i.e. secretary, to someone)":

- wa-kāna yaktubu li-l-Walīd Bukayr ibn aš-Šammāh "Bukayr ibn aš-Šammāh was $k a \overline{t i b}$ (i.e. secretary) to (Umayyad caliph) al-Walīd";"97

- kitāba "the art of writing"; "the office of secretary":

- wa-fi-hā waliya 'Awn ad-Dīn Yahyā ibn Hubayra kitābat dīwān az-zimām biBag்dād "In (this year) 'Awn ad-Dīn Yahyā ibn Hubayra became the secretary of dīwān az-zimām in Bagdad"; 98

91 SELLHEIM / SOURDEL 1997: 754-5.

92 ĞAHŠIYĀRĪ 1988: 15-17.

93 BARTHOLD 1912: 260.

94 MASÛDÎ 1894: 340; NICHOLSON 1907: 257 (with reference to M.J. De Goeje).

95 BARTHOLD 1912: 260.

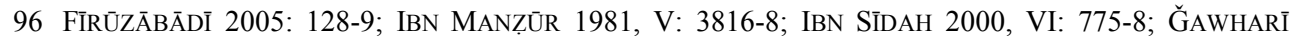
1990, I: 208-9; LANE 1968, VII: 2589-91; MA'LŪF 1996: 671-2; RĀZī 1986: 234-5; ZABĪDĪ 1965, IV: 100-7; ZAMAHֵŠ̌Lī 1996: 383.

97 ĞAHŠIYĀRİ 1988: 4.

98 IBN AL-AṬīR 1987-2003, IX: 348. 


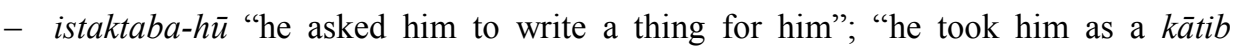
(secretary)":

fa-lamma waliya Muș'ab al-Irāq, istaktaba ibn Abī Farwa "When Muș'ab became wāll (governor) of Iraq, he took ibn Abī Farwa as a kātib (secretary)". ${ }^{99}$

As we can observe, the denominative verbs kataba and istaktaba developed their semantic meanings "to be a kätib (sectretary)" and "to take someone as a kātib (secretary)", respectively, on the ground of the semantic shift "the name of position" > "to hold this position" / "to appoint someone to this position" (see above).

Thus, a bulk of material (basically Classical Arabic lexicographic and historiographic works, Western Orientalist studies) treated in my research permits me to draw the conclusion that the term wazir definitely has an Arabic origin and hence I may corroborate the idea about exclusively Arabic roots of this term put forward in Classical Arabic lexicographic treatises. Concerning the question of the foundation of the institution of vizierate (wizāra) as it was known in 'Abbāsid era I am inclined to state that it has a native Arabic background, though Persian (namely Sassanid) influence cannot be ruled out. The linguistic and historical development of the notion of ministry in Arabic statehood tradition will be investigated in a further paper.

\section{References}

\section{Primary sources}

AzHARĪ. 1964-1967. Abū Manșūr Muhammad ibn Aḥmad al-Azharī. Tahd̄īb al-lugia, ed. 'Abd asSalām Muḥammad Hārūn, Muḥammad 'Alī an-Nağğār, 15 vols. al-Qāhira: al-Mu'assasa alMișriyya al-'Āmma li-t-Ta'līf wa-l-Anbā' wa-n-Našr: ad-Dār al-Mișriyya li-t-Ta'līf wa-tTarğama.

BADAwI, el-Said / HINDS, Martin. 1986. A dictionary of Egyptian Arabic: Arabic-English. Beirut: Librairie du Liban.

COHEN, David (avec la collaboration de François BRON et Antoine LONNET). 1996. Dictionnarie des racines sémitiques ou attestées dans les langues sémitiques / comprenant un fichier comparatif de Jean Cantineau, Vol. II, fasc. 6 (W-WLHP). Leuven: Peeters.

De BibersteIn KAZIMIRSKI, Albert. 1860. Dictionnaire Arabe-Français: contenant toutes les racines de la langue arabe, leurs dérivés, tant dans l'idiome vulgaire que dans l'idiome littéral, ainsi que les dialectes d'Alger et de Maroc, 2 vols. Paris: Maisonneuve.

DE SACY, M. le Baron Silvestre. 1822. Les Séances de Hariri, publiées en Arabe avec un commentairie choisi. Paris: Imprimerie royale.

DozY, Reinhart Pieter Anne. 1881. Supplement aux dictionnaires arabes, 2 vols. Leide: E.J. Brill.

EBN Al-BALH̄ī. 1385 SH. Fārs-nāma, ed. Guy le Strange, R.A. Nicholson. Teherān: Entešarāt Asāṭîr.

FīrūZĀBĀDĪ. 2005. Mağd ad-Dīn Muhammad ibn Yáqūb al-Fīrūzābādī aš-Šīrāzī. al-Qāmūs almuḥịt, ed. Muḥammad Na'īm al-'Araqsūsī. Bayrūt: Maktabat ar-risāla.

99 ĞAHŠIYĀRI 1988: 33.

$J A I S$ • 15 (2015): 227-244 
ĞĀHIZz. 1914. Abū 'Uțmān 'Amr ibn Baḥr al-Ğāhiz. Kitāb at-tāğ fì ahlāq al-mulūk, ed. Aḥmad Zakī Bāšā. al-Qāhira: al-Mațba'a al-Amīrīya.

ĞAHŠIYĀRĪ. 1988. Abū 'Abdallāh Muḥammad ibn 'Abdūs al-Ğahšiyārī. Kitāb al-wuzarāa' wa-l-kuttāb, ed. Ḥasan az-Zain. Bayrūt: Dār al-Fikr al-Ḥadīt.

ĞAWHARĪ. 1990. Ismā̄̄îl ibn Ḥammād al-Ğawharī. aṣ-Șihāḥ: Tāğ al-lugia wa-șihāh al-'Arabiyya, ed. Aḥmad 'Abd al-Ġafūr 'Aț̣ār, 6 vols. Bayrūt: Dār al-iilm li-l-malāyīn.

IBN AL-AṬīr. 1987-2003. 'Izz ad-Dīn Abū 'l-Ḥasan 'Alī ibn Abī al-Karam Muhammad ibn Muhammad ibn 'Abd al-Karīm ibn 'Abd al-Wāḥid aš-Šaybānī ibn al-Atīr. al-Kāmil fì-t-tārīhn, ed. Muḥammad Yūsuf ad-Daqqāq, 11 vols. Bayrūt: Dār al-Kutub al-'Tlmiyya.

IBN ĞAMĀ'A. 1985. Badr ad-Dīn ibn Ğamā'a. Tahrīr al-Ahkām fì tadbīr ahl al-Islām, ed. Fu'ād 'Abd al-Mun'im Aḥmad. Qaṭar: Ri'āsat al-maḥākim aš-šar'iyya wa-š-šu'ūn ad-dīniyya.

IBN KAṬīr. 1998. al-Imām al-Ḥāfiẓ 'Imād ad-Dīn Abū 'l-Fidā' Ismāēil ibn 'Umar ibn Kat̄īr adDimašqī. Tafsīr al-Qur'ān al-'azì̄m, ed. Muhammad Ḥusayn Šams ad-Dīn, 8 vols. Bayrūt: Dār alKutub al-'Ilmiyya.

IBN MANẒŪR. 1981. ibn Manzūr. Lisān al-'Arab, ed. 'Abd Allāh 'Alī al-Kabīr, Muḥammad Aḥmad Ḥasab Allāh, Hāšim Muḥammad aš-Šādilī̄, 6 vols. al-Qāhira: Dār al-Ma‘ārif.

IBN Qutayba. Abū Muḥammad 'Abd Allāh ibn Muslim Ibn Qutayba ad-Dīnawarī. Kitāb 'uyūn al$a h b \bar{a} r, 4$ vols. Bayrūt: Dār al-Kitāb al-'Arabī.

IBN SīDAH. 2000. 'Alī Ibn Ismā̄̄ll ibn Sīdah. al-Muhkam wa-l-muhīt al-a'ẓam fì-l-lugia, ed. 'Abd alHạīè Hindāwī, 11 vols. Bayrūt: Dār al-Kutub al-'Ilmiyya.

IBN TAĞRīBIRDī. 1992. Ğamāl ad-Dīn Abū 'l-Mahāsin Yūsuf ibn Tag̉rībirdī al-Atābikī. an-Nuğūm azzāhira fì mulūk Miṣr wa-l-Qāhira, ed. Muḥammad Ḥusayn Šams ad-dīn, 16 vols. Bayrūt: Dār alKutub al-'Ilmiyya.

JA'QŪBĪ. 1883. Ibn Wadhih qui dicitur al-Ja'qubi historiae, ed. M. Th. Houtsma, 2 vols. Lugduni Batavorum: E.J. Brill

KanE, Thomas Leiper. 1990. Amharic-English dictionary, 2 vols. Wiesbaden: Otto Harrassowitz.

KLEIN, Ernest. 1987. A comprehensive etymological dictionary of the Hebrew language for readers of English. New York: Macmillan; London: Collier Macmillan.

LANE, Edward William. 1968. Arabic-English lexicon, 8 parts. Beirut: Librairie du Liban.

LESLAU, Wolf. 1991. Comparative dictionary of Gə’วz (Classical Ethiopic). Gə‘əz-English / EnglishGə'əz with an index of the Semitic roots. Wiesbaden: Otto Harrassowitz.

-. 1996. Concise Amharic Dictionary: Amharic-English : English-Amharic. Berkeley and Los Angeles: University of California Press.

MAḤALLī / SUYŪṬī. al-Qur'ān al-Karīm bi-r-rasm al-'uțānī wa-bi-hāmiši-hi Tafsīr al-imāmayn alğalīlayn Ǧalāl ad-Dīn Muḥammad ibn Aḥmad ibn Muḥammad al-Maḥallī wa-Ğalāl ad-Dīn 'Abd ar-Raḥmān ibn Abī Bakr as-Suyūṭ̣̂, mudayyal ${ }^{\text {an }}$ bi-Kitāb Lubāb an-nuqūl fì asbāb an-nuzūl lisSuyūtịi, ed. Faḍīlat al-muḥaddit al-muhaqqiq aš-Šayh 'Abd al-Qādir al-Arnāēụt. Dār ibn Katīr.

MA'LŪF, Luwīs. 1996. al-Munǧid fì 'l-lug̉a. Bayrūt: al-Maṭba'a al-Kātūīīkiyya.

MASÛDî. 1894. Bibliotheca geographorum arabicorum. V. VIII. Al-Masûdî. Kitâb at-tanbîh wa'lšrâf, ed. M.J. de Goeje. Lugduni Batavorum apud E.J. Brill.

MAS'ŪDĪ. 1938. Abū 'l-Ḥasan 'Alī ibn al-Ḥusayn al-Mas'ūdī. at-Tanbīh wa 'l-išrāf, ed. 'Abd Allāh Ismā̄îl aṣ-Ṣāwī. al-Qāhira: Dār aṣ-Ṣāwī. 
MĀWARDī. 1976. Abū 'l-Ḥasan 'Alī ibn Muhammad ibn Ḥabīb al-Māwardī. al-Wizāra. Adab alwazīr, ed. Muhammad Sulaymān Dāwūd, Fu'ād 'Abd al-Mun'im Aḥmad. al-Iskandariyya: Dār alǦāmi'̄ât al-Miṣrīyya.

MĀWARDĪ. 1979. Abū 'l-Ḥasan 'Alī ibn Muhammad ibn Ḥabīb al-Māwardī. Qawānīn al-wizāra wasiyāsat al-mulk, ed. Rị̣wān as-Sayyid. Bayrūt: Dār aț-Ṭalî‘a.

MĀWARDī. 1989. Abū 'l-Ḥasan 'Alī ibn Muhammad ibn Ḥabīb al-Māwardī. Kitāb al-Aḥkām assulțāniyya wa-l-wilāyāt ad-dīnīyya, ed. Aḥmad Mubārak al-Baġdādī. al-Kuwayt: Maktabat Dār ibn Qutạba.

Miskawayh. 2003. Abū 'Alī Aḥmad ibn Muḥammad ibn Ya'qūb Miskawayh. Tağārib al-umam wa ta āqub al-himam, ed. Sayyid Kasrawī Hasan, 5 vols. Bayrūt: Dār al-kutub al-'ilmiyya.

Online Etymology Dictionary; available at $<\mathrm{http}$ ///etymonline.com>.

QuRṬUBĪ. 2006. Abū 'Abd Allāh Muhammad ibn Ahmmad ibn Abī Bakr al-Qurțubī. al-Ğāmi' li-ahkām al-Qur'ān wa-l-mubayyan li-mā tadammana-hū min as-sunna wa-āy al-furqān, ed. 'Abdallāh ibn 'Abd al-Muḥsin at-Turkī, 24 vols. Bayrut, Mu'assasat ar-Risāla.

RĀZī. Muḥammad ibn Abī Bakr ibn 'Abd al-Qādir ar-Rāzī. Muḥtār aṣ-Ṣiḥạh. Bayrūt: Maktabat Lubnān, 1986.

ȘĀBĪ. Abū 'l-Ḥasan al-Hilāl ibn al-Muhassin aṣ-Șābī. al-Wuzarā', aw Tuhfat al-umarā' fì tārīh alwuzarā', ed. 'Abd as-Sattār Aḥmad Farrāğ. Maktabat al-A'yān.

ŠĀH-NĀME. 1960-71. Šax-nāme: Kritičeskij tekst, ed. A. Nushin, 9 vols. Moscow: Izdatel'stvo Nauka.

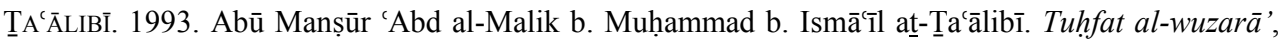
ed. Sa'ad Abū Diya. 'Ammān: Dār al-Bašīr.

TABARi/Bel'Ami. 1867-1874. Chronique d'Abou Djafar Mohammed ben Djarir ben Yezid Tabari, traduite sur la version persane d'Abou 'Ali Mohammed Bel'ami, d'après les mss. de Paris, Gotha, Londres et Canterbury, 4 vols. Paris: Imprimerie impériale.

ṬABARĪ. 1879-1901. Annales quos scripsit Abu Djafar Mohammed ibn Djarir at-Tabari cum aliis editit M.J. de Goeje. Ser. 1-3. Lugd. Bat: E.J. Brill.

ṬABARĪ. 1960. Abū Ğa'far Muhammad ibn Ğarīr aț-Ṭabarī. Tārīh at-Tabarī:Tārīh ar-rusul wa-lmulūk, ed. Muḥammad Abu-l-Faḍl Ibrāhīm, 11 vols. Miṣr: Dār al-Macārif.

ȚABARĪ. 2001. Abū Ğa‘far Muhammad ibn Ğarīr at-Ṭabarī. Ğāmi' al-bayān 'an ta'wäl āy-l-Qur'ān, ed. 'Abdallāh ibn 'Abd al-Muḥsin at-Turkī, 25 vols. al-Qāhira: Hağar li-țtṭibā'a wa-n-našr wa-ttawZī'.

WAKī‘. Muḥammad ibn Ḩalaf ibn Ḥayyān Wakī'. Ahbār al-quḍāt, 3 vols. Bayrūt: 'Ālam al-kutub.

WAHRMUND, Adolf. 1887. Handwörterbuch der neu-arabischen und deutschen Sprache, 2 vols. Giessen: J. Ricker.

WeHR, Hans. 1980. A Dictionary of Modern Written Arabic. Edited by J. Milton Cowan. Beirut: Librairie du Liban, London: Macdonald \& Evans Ltd.

ZABĪDĪ. 1965. Muhammad Murtaḍā al-Ḥusaynī az-Zabīdī. 1965-. Tāğ al-'arūs min ğawāhir al-qāmūs, ed. 'Abd as-Sattār Aḥmad Farrāğ, 40 vols. al-Kuwayt: Wizārat al-iršād wa-1-anbā'.

YA'QŪBĪ. 2010. Aḥmad ibn Ab̄̄ Ya'qūb ibn Ğađfar ibn Wahb ibn Wāḍiḥ al-Kātib al-'Abbāsī alYa'qūbī. Tārīh al-Ya'qūbī, ed. 'Abd al-Amīr Muhannā, 2 vols. Bayrūt: Šarikat al-A'lamī li-1mațbūāat.

$J A I S$ • 15 (2015): 227-244 
ZAMAHŠARĪ. 1996. Ğārallāh Abū 'l-Qāsim Maḥmūd ibn 'Umar az-Zamahš̌arī. Asās al-Balāga. Bayrūt: Maktabat Lubnān.

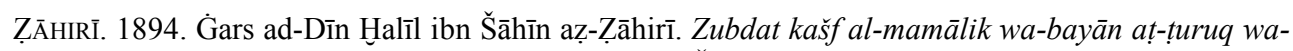
l-masālik, ed. Būlas Rāways. Bārīs: al-Maṭbaca al-Ğumhūriyya.

\section{Secondary sources}

Al-HiLĀLİ, Muḥammad Taqiyy ad-Dīn / KHĀN, Muḥammad Muḥsin. 1418 [1997]. Translation of the meanings of the Noble Qur'an in the English language. al-Madīna al-Munawwara: Muğamma' al-Malik Fahd li-țibāacat al-Muṣhaf aš-Šarīf.

BABINGER, Franz. 1993. "Wazīr”. EI I VIII: 1135-1136.

Boyce, Mary. 1968. The Letter of Tansar, trans. Boyce Mary. Rome: Istituto Italiano per il Medio ed Estremo Oriente.

BARTHOLD, Wilhelm. 1912. "Die persische Su'ubija und die moderne Wissenschaft". Zeitschrift für Assyriologie und verwandte Gebiete, XXVI: 249-266.

BRownE, Edward Granville. 1900. "Some Account of the Arabic Work Entitled 'Niháyatu'l-irab fí akhbári'l-Furs wa'l-'Arab', particularly of that part which treats of the Persian kings". The Journal of the Royal Asiatic Society of Great Britain and Ireland: 195-259.

BRownE, Edward Granville. 1908 [reprinted 1919]. A literary history of Persia. From the earliest times until Firdawsi. London: T. Fisher Unwin Ltd: Adelphi Terrace.

Chaumont, Marie-Louise. 2001. "Framadār". Encyclopcedia Iranica, ed. Ehsan Yarshater, X/2: 125126; available online at $<\mathrm{http}$ //www.iranicaonline.org/articles/framadar $>$.

Christensen, Arthur. 1907. L'empire des Sassanides. Le peuple, l'état, la cour. Kobenhavn: Bianco Lunos Bogtrykkeri.

— . 1944. L'Iran sous les Sassanides. Copenhague: E. Munksgaard.

DARMESTETER, James. 1883. Études iraniennes. Paris: F. Vieweg, Libraire-éditeur.

—. 1894. "Lettre de Tansar au roi de Tabaristan", trans., ed. James Darmesteter. Journal Asiatique, série 9, t. III: 185-250, 502-555.

$E I^{I}=$ E.J. Brill's first encyclopaedia of Islam (1913-1936), ed. M. Th. Houtsma, T.W. Arnold, R. Basset, R. Hartmann, Leiden: E.J. Brill.

$E I^{2}=$ Encyclopcedia of Islam, 2nd edition, ed. P.J. Bearman, Th. Bianquis, C.E. Bosworth, E. van Donzel and W.P. Heinrichs et al., Leiden: E. J. Brill.

Enger, Max. 1859. "Ueber das Vezirat". Zeitschrift der Deutschen Morgenländischen Gesellschaft, Bd. XIII: 239-248.

HoRn, Paul. 1893. Grundriss der neupersischen Etymologie. Strassburg: Verlag von Karl J. Trübner.

GEIGER, Wilhelm. 1891. "Das Yātkār-i Zarīrān und sein Verhältnis zum Šāh-nāme”. Sitzungberichte der philosophisch-philologischen und historischen Classe der k. b. Akademie der Wissenschaften zu München. Jahrgang 1890. Bd. III: 43-84.

GoITEIN, Shelomo Dov. 1966. The origin of the vizierate and its true character. Studies in Islamic History and Institutions. Leiden: E.J. Brill.

IBN EL-ÇAÏRAFI. 1914. "Code de la Chancellerie d'État (période fâtimide), traduit par M. Herni Massé". Le Bulletin de l'Institut français d'archéologie orientale, XI: 65-120.

JASTROW, Marcus. 1903. A Dictionary of the Targumim, the Talmud Babli and Yerushalmi, and the Midrashic literature, 2 vols. London: W.C.: Luzac \& Co., New York: G.P. Putnam's sons. 
Kent, Ronald G. 1950. Old Persian: Grammar, Texts, Lexicon. American Oriental Society: New Haven, Connecticut.

NichOLSON, Reynold Alleyne. 1907. A Literary History of the Arabs. New York: Charles Scribner's Sons.

NöLDEKE, Theodor. 1879a. "Geschichte des Artachšîn i Pâpakân" / aus dem Pehlewi übersetzt, mit Erläuterungen und einer Einleitung versehen von Th. Nöldeke. Beiträge zur Kunde der indogermanischen Sprachen. Bd. IV: 22-69.

- .1879b. Geschichte der Perser und Araber zur Zeit der Sasaniden / Aus der Arabischen Chronik des Tabari-übers. und mit ausführlichen Erläuterungen und Ergänzungen versehn von Th. Nöldeke. Leyden: E.J. Brill.

RAJABZADEH, Hashem / TAFAżżolī, Ahmad. 1993. "Dabīr”. Encyclopcedia Iranica, ed. Ehsan Yarshater. Vol. VI, Fasc. 5: 534-539; available online at <http://www.iranicaonline.org/ articles/dabir-secretary-scribe>.

Sellheim, Rudolf / Sourdel, Dominique. 1997. "Kātib" (i. in the Caliphate). EI IV: 754-760.

SOURDEL, Dominique. 1959-60. Le vizirat 'abbāside de 749 à 936 (132 à 324 de l'hégire), 2 vols. Damas: Institut français de Damas.

ZAmAn, Muhammad Qasim. 2002. "Wazīr" (I. In the Arab world. 1. The 'Abbāsids). EI² XI: 185-197.

(C) Ivan V. Sivkov, Dept. of Middle East Studies, Institute of Philology, Taras Shevchenko National University of Kyiv, Ukraine 4 a_b_c_6662001@yahoo.com 